\title{
Entry and Exit in Retailing: Incentives, Barriers, Displacement and Replacement
}

\author{
MARTIN CARREE and ROY THURIK * \\ Centre for Advanced Small Business Economics, Erasmus University Rotterdam, P.O. Box 1738, \\ 3000 DR Rotterdam, The Netherlands \\ EIM Small Business Research and Consultancy, P.O. Box 7001,2701 AA Zoetermeer, The \\ Netherlands
}

\begin{abstract}
In this study the determinants of entry and exit and the interrelationship between these market phenomena are investigated. We examine incentives, barriers, displacement and replacement for a panel data-set of 23 Dutch shoptypes for the 1981-1988 period. Results indicate that profit as a ratio of modal income, growth of consumer spending and growing unemployment are important incentives to enter and disincentives to exit. Requirements of floorspace and professional skills appear to reduce entry rates. We find evidence for entry and exit to interact but not to be simultaneously determined. The implication being that entry (exit) has a separate influence on exit (entry) next to market incentives and entry and exit barriers.
\end{abstract}

Key words: Entry, exit, retailing, displacement, replacement.

\section{Introduction}

The selection process in which markets choose between established and entrant firms has a vital contribution to the transformation of industries over time. Industries with low birth and death rates are likely to be more vulnerable to an inadequate allocation of resources, limited innovativeness, and some form of formal or tacit collusion (Geroski and Jacquemin (1985)). The continuous flows of entry and exit represent a changing pool of potentially strong competitors. Beesley and Hamilton (1984) describe them as the seedbed of new activities from which will emerge the successful businesses and industries of the future. High barriers to entry and exit may therefore be serious impediments to dynamic market efficiency.

Entry and cxit rates of firms differ strongly across industries and over time (Dunne, Roberts and Samuelson (1988), Van Herck (1984)). In empirical studies this variation in the intensity of the selection process by which incumbents are displaced by new entrants is explained by variation in profitability and market

* The authors are indebted to Kees Bakker, Anne Bruijns, Henk Pays, Frans Pleijster and Herman van Schaik of the EIM Small Business Research and Consultancy (EIM) for providing and elaborating the data. Helpful suggestions were received from René Belderbos, Christiaan Heij and Aad Kleijweg. We are especially grateful to the Bedrijfssignaleringssysteem (BSS) of EIM and the Central Registration Office (CRK) for placing the data at our disposal. Financial support from the Netherlands Organization for Scientific Research (NWO) is acknowledged. 
growth and by variation in the height of entry and exit barriers. A wide variety of entry barriers are supposed and found to influence entry decisions. A survey of a total of nineteen different market entry barriers can be found in Karakaya and Stahl (1989). Most studies incorporate the effects of profitability and market growth on rates of entry and exit, but the empirical evidence is mixed (see Section II).

Entry and exit are interrelated market phenomena. Incentives to enter, like high profitability and strong market growth, are also disincentives to exit. Many entry barriers can also be considered exit barriers and vice versa (Eaton and Lipsey (1980), Shapiro and Khemani (1987)). Entry and exit may however not only be influenced by the same overall market conditions, but could also respond directly to each other (Rosenbaum and Lamort (1992)). Entering firms may replace and/or displace exiting firms. Replacement occurs when exit causes entry. Exit may enhance opportunities for (potential) entrepreneurs to enter. Displacement occurs when entry causes exit. Entry may adversely affect survival chances of incumbent firms. Turnover of firms may be strongly influenced by the extent of these replacement and displacement effects.

The aim of this paper is to extend and supplement empirical evidence on the processes of entry and exit as built up since Mansfield (1962). There are three contributions in this study to the investigation of entry and exit. First, it examines the causal interrelationship of replacement and displacement using an extensive and rich panel data-set at a low level of aggregation. Second, it is the first to explain determinants of entry and exit in a non-manufacturing industry, viz. retailing. The retail sector has an important contribution to the economy. It accounts for about $23 \%$ of the total number of economically active enterprises and for about $13 \%$ of total labour force in the Dutch private sector in 1988 (source: Bode (1990)). The total number of economically active enterprises in retailing $(92,000)$ in the Netherlands is twice of that in manufacturing $(46,700)$ (source: EIM (1991)). ${ }^{1}$ Third, it stands out in that it concentrates on a comparatively simple entrepreneurial activity. The setting up or closing down of a venture in retailing generally demands much less capital, time and knowledge investment than in manufacturing. This is due to the more limited size of retail ventures and the more clearly structured retail market environment resulting from the limited impact of innovations, complex networkdependencies and international competition. Hence, retailing can be regarded as a promising testing area for establishing the influence of market incentives on entry and exit rates.

In Section II we examine patterns of firm entry and exit in Dutch retailing and discuss previous findings in the empirical entry and exit literature. We provide a survey of the effects of profitability and market growth on entry and exit as

${ }^{1}$ Employment shares of the retail trade in the private sector do not differ much across countries in Western Europe. The total number of employees in the retail sector in 1988 in France, Germany, the Netherlands and the United Kingdom were (percentage of total employment in the private sector between brackets): 1,639,000 (12.1), 2,254,000 (11.5), 527,700 (12.6) and 2,615,000 (12.8), respectively (source: Vogelesang, Broadbridge and Zanderighi (1992)). 
found in 44 studies. Section III is used for a discussion of the determinants of entry and exit that are used in this study. In Section IV we pay special attention to the problems related to the estimation of displacement and replacement effects. In Section V we present the data and empirical results. Section VI is used for concluding remarks.

\section{Patterns of Entry, Exit and Their Determinants}

The average annual entry and exit rates for Dutch shoptypes (retail industries) for the 1981-1988 period can be found in Table $I^{2}$ We compare these figures with those presented by Dunne, Roberts and Samuelson (1988) for U.S. manufacturing for the 1963-1982 period. Patterns and determinants of entry and exit in this sector have been studied intensively in the past decades. The average annual entry and exit rates are 0.083 and 0.091 in Dutch retailing, while they are 0.081 and 0.074 in U.S. manufacturing. ${ }^{3}$ The lowest and highest average entry rates in Dutch shoptypes are 0.035 for tobacco shops and 0.154 for florists. The corresponding figures for U.S. manufacturing industries (at two-digit level) are 0.043 for tobacco (SIC 21) and 0.121 for instruments (SIC 38). The lowest and highest average exit rates in Dutch retailing are 0.052 for bicycles and 0.138 for furnishing stores with mixed assortment. The lowest average exit in U.S. manufacturing is again found in tobacco (SIC 21) at 0.047 and highest average exit in apparel (SIC 23) at 0.095. Entry and exit rates in Dutch retailing have a correlation coefficient of 0.78 (over one year periods, see Table II). Dunne, Roberts and Samuclson also found entry and exit to be highly correlated. They found a coefficient of 0.27 over five year periods. One may expect correlation between average entry and exit rates to be somewhat higher in retailing than in manufacturing. This is a consequence of the lower probability of survival of new small firms in retailing (38.4 percent for a ten year-period, U.S. data) versus those in manufacturing (46.9 percent) (source: Phillips and Kirchhoff (1989)).

Empirical studies of the determinants of entry and exit have received growing attention since Orr's influential paper (Orr (1974)). Table III presents a total of 44 studies with characteristics of the data-set used (country, number of industries, period, measure of entry or exit). All these studies are strictly confined to manufacturing industries, with the exception of Highfield and Smiley (1987), where a small proportion of non-manufacturing industries is incorporated into the data-set. There has been considerable progress in the empirical entry and exit literature since Mansfield's 1962 article. ${ }^{4}$ First, data for several countries and for highly disaggregated industries have been used. Some of the more recent studies also use panel

2 Throughout this study entry rate (ENTRY) is defined as the total number of firms entering from period $t-1$ to $t$ divided by the total number of firms in period $t-1$. The exit rate (EXIT) is the total number of firms leaving from period $t-1$ to $t$ divided by the total number of firms in period $t-1$.

${ }^{3}$ The figures for Dutch retailing relate to the 23 shoptypes discussed in the present paper.

4 This has also led to important progress in the theoretical line of research (see e.g. Hopenhayn (1992) and Jovanovich and Lach (1989)). 
TABLE I. Entry, exit, profitability and demand growth in shoptypes

\begin{tabular}{llllr}
\hline Shoptype & ENTRY & EXIT & PMI $_{-1}$ & DCS $_{-1}$ \\
\hline Supermarkets with butcher's shop & 0.079 & 0.098 & 1.63 & 0.006 \\
Butchers & 0.071 & 0.079 & 1.09 & -0.000 \\
Greengrocers & 0.083 & 0.094 & 0.88 & 0.034 \\
Dairy shops & 0.051 & 0.081 & 0.75 & 0.014 \\
Fish shops & 0.113 & 0.107 & 0.85 & 0.005 \\
Bakers & 0.060 & 0.062 & 1.60 & 0.011 \\
Confectioners & 0.092 & 0.107 & 1.27 & 0.014 \\
Tobacco shops & 0.035 & 0.070 & 0.84 & -0.035 \\
Liquor stores & 0.085 & 0.111 & 0.54 & -0.010 \\
Textiles mens wear & 0.140 & 0.125 & 1.82 & 0.002 \\
Shoes & 0.071 & 0.073 & 1.26 & 0.019 \\
Household goods & 0.087 & 0.089 & 0.85 & 0.004 \\
Furnishing stores, mainly furniture & 0.100 & 0.105 & 1.92 & -0.015 \\
Furnishing stores, mainly clothing material & 0.140 & 0.125 & 1.41 & -0.014 \\
Furnishing stores, mixed assortment & 0.109 & 0.138 & 1.91 & -0.015 \\
Paint, glass, wall-paper & 0.049 & 0.082 & 1.09 & 0.006 \\
Ironmongers/do-it-yourself shops & 0.052 & 0.066 & 1.02 & 0.006 \\
Bicycles & 0.041 & 0.052 & 0.88 & -0.020 \\
Photographer's shops & 0.082 & 0.079 & 1.27 & 0.062 \\
Watches, gold, silver & 0.080 & 0.083 & 1.30 & -0.018 \\
Druggists & 0.053 & 0.060 & 1.17 & 0.051 \\
Florists & 0.154 & 0.132 & 0.67 & 0.026 \\
Pet shops & 0.089 & 0.086 & 0.61 & 0.006 \\
& & & & \\
Mean & 0.083 & 0.091 & 1.16 & 0.006 \\
\hline
\end{tabular}

Note: The variables ENTRY, EXIT, PMI and DCS stand for the shoptype's entry rate, exit rate, average profit (divided by modal income) and the growth of consumer spending, respectively. Figures are averages over the 1981-1988 period.

data. The use of panel data is of great importance in examining a process as highly dynamic as entry and exit (Schmalensee (1989)). Second, different types of entry and exit have been examined. One may expect that incentives and barriers differ between diversifying and specialist entry, between domestic and foreign entry and between entry by small and by large firms. Third, the empirical relevance of a large number of different entry and exit barriers has been investigated. Fourth, displacement and replacement effects tend to be incorporated in recent studies. See Geroski (1991b) for a more general exposition of the causes and effects of entry and exit.

Most studies incorporate two incentives to enter (or disincentives to exit): a measure of profitability and a measure of market growth. Table III presents the reported significance of the effects of profitability and growth on entry and exit in 
TABLE II. Correlations of entry, exit, profitability and demand growth

\begin{tabular}{lllllr}
\hline & ENTRY & EXIT & PMI $_{-1}$ & PRI $_{-1}$ & DCS $_{-1}$ \\
\hline ENTRY & & $0.783^{*}$ & $0.219^{*}$ & -0.119 & 0.070 \\
EXIT & $0.617^{*}$ & & 0.122 & -0.072 & -0.133 \\
PMI_1 & $0.180^{*}$ & $-0.148^{*}$ & & $-0.231^{*}$ & $0.182^{*}$ \\
PRI $_{-1}$ & 0.039 & -0.012 & $0.185^{*}$ & & $0.154^{*}$ \\
DCS $_{-1}$ & 0.108 & $-0.155^{*}$ & $0.422^{*}$ & 0.144 & \\
\hline
\end{tabular}

Note: Correlations to the left of the diagonal are adjusted for industry effects: the per shoptype mean of the variable is subtracted before the correlations are estimated. Correlations to the right of the diagonal are not adjusted for industry effects. Estimates which are significant at a $5 \%$-significance level are denoted by ${ }^{*}$. The variable PRI stands for average profit divided by equity. See also note to Table $\mathrm{I}$.

the 44 studies. This overview provides an adequate benchmark against which to compare our results on the effects of profitability and market growth on entry and exit in the retail sector. A summary of the findings is presented in Table IV. In 20 out of 35 empirical results a significant positive effect of (a measure of) profitability on (a measure of) gross entry is found. A significant negative effect is only found by Wagner (1994) when using a reweighted regression approach. In 28 out of 37 empirical results a significant positive effect of (a measure of) market growth on (a measure of) gross entry is found. No study reports a significant negative effect. The results for gross exit are somewhat less clear-cut. Only 4 out of 10 results show a significant negative effect of profitability on gross exit, while 3 results show the opposite. The results for market growth are more straightforward: 5 out of 9 results are negative and significant, while no study finds a significant positive effect. Some studies use net entry (gross entry minus gross exit) as dependent variable. Significant positive effects of (a measure of) profitability and market growth on (a measure of) net entry are found in 8 out of 13 and 13 out of 18 empirical results, respectively. In both cases only one result shows a significant negative effect.

\section{The Determinants of Entry and Exit in Retailing}

In this paper we incorporate two measures of profitability in the entry and exit equations. The first is profit divided by modal income (PMI). Most (potential) entrepreneurs in retailing are small independents. About 88,600 out of 92,000 retail firms in the Netherlands have less than 10 employees, while 3,200 have 10 to 100 employees and 200 have more than 100 employees (source: EIM (1991)). As a small independent's profit generally equals his income (before taxes), we may consider PMI to be a good indicator for the attractiveness to enter a certain shoptype. A more traditional measure of profitability is profit as a ratio of equity (PRI). This corresponds to usual measures of return on investment. The effect of 
TABLE III. Empirical studies into the determinants of entry and exit

\begin{tabular}{|c|c|c|c|c|c|c|c|}
\hline Study & Country & Ind & Period & Mea & Prof & Grow & Remarks \\
\hline \multirow[t]{2}{*}{ Mansfield (1962) } & USA & 4 & $1916-59$ & GRE & $+t$ & $\mathrm{n}$ & \\
\hline & & & & GRX & - & $\mathrm{n}$ & \\
\hline Marcus (1967) & USA & 17 & $1951-55$ & GRX & - & $\mathrm{n}$ & \\
\hline Orr (1974) & Canada & 71 & $1964-67$ & NNE & 0 & $0 /+$ & \\
\hline Duetsch (1975) & USA & 307 & $1958-67$ & NRE & $0 /+$ & ++ & \\
\hline \multirow[t]{2}{*}{ Gorecki (1975) } & UK & 44 & $1958-63$ & NRE & $\mathrm{n}$ & ++ & Diversifying entry \\
\hline & & & & NRE & $\mathbf{n}$ & ++ & Specialist entry \\
\hline \multirow[t]{2}{*}{ Gorecki (1976) } & Canada & 62 & $1964-67$ & NNE & 0 & 0 & Domestic entry \\
\hline & & & & NNE & $\mathrm{n}$ & ++ & Foreign entry \\
\hline Hirschey (1981) & USA & 87 & $1947-72$ & NRE & $0 \%$ & ++ & \\
\hline Masson and Shaanan (1982) & USA & 37 & $1958-63$ & GSE & + & 0 & \\
\hline Creedy and Johnson (1983) & UK & 16 & $1966-77$ & GRE & + & $\mathrm{n}$ & \\
\hline \multirow[t]{4}{*}{ Shapiro (1983) } & Canada & 131 & $1972-76$ & GNE & + & + & Domestic entry \\
\hline & & & & GNE & + & 0 & Foreign entry \\
\hline & & & & GNX & $0 /+$ & 0 & Domestic exit \\
\hline & & & & GNX & 0 & 0 & Foreign exit \\
\hline Duetsch (1984) & USA & 95 & $1963-72$ & NNE & + & ++ & \\
\hline \multirow[t]{2}{*}{ Hause and Du Rietz (1984) } & Sweden & 39 & $1954-68$ & GEE & $\mathbf{n}$ & + & \\
\hline & & & & GRE & $\mathrm{n}$ & + & \\
\hline Hilke (1984) & USA & 16 & $1950-66$ & GSE & 0 & ++ & \\
\hline \multirow[t]{2}{*}{ Hamilton (1985) } & Scotland & 86 & $1976-80$ & GRE & 0 & + & Independent entry \\
\hline & & & & GRE & 0 & + & Dependent entry \\
\hline Kessides (1986) & USA & 262 & $1972-77$ & NNE & $*$ & ++ & \\
\hline \multirow[t]{2}{*}{ Khemani and Shapiro (1986) } & Canada & 143 & $1972-76$ & GNE & ++ & ++ & \\
\hline & & & & GRE & 0 & + & \\
\hline \multirow[t]{2}{*}{ MacDonald (1986) } & USA & 46 & $1976-82$ & GEE & 0 & ++ & Specialist entry \\
\hline & & & & GEX & $\mathrm{n}$ & 0 & Specialist exit \\
\hline Masson and Shaanan (1986) & USA & 26 & $1958-63$ & GSE & + & ++ & \\
\hline \multirow[t]{2}{*}{ Baldwin and Gorecki (1987) } & Canada & 141 & $1970-79$ & GNE & + & ++ & Domestic entry \\
\hline & & & & GNE & 0 & 0 & Foreign entry \\
\hline Highfield and Smiley (1987) & USA & 60 & $1976-81$ & GRE & ++ & ++ & \\
\hline Lieberman (1987) & USA & 38 & $1952-82$ & GDE & $\mathrm{n}$ & ++ & \\
\hline Masson and Shaanan (1987) & USA & 43 & $1964-67$ & NNE & $0 /+$ & 0 & \\
\hline Schwalbach (1987) & Germany & 122 & $1977-82$ & GSE & ++ & ++ & Diversifying entry \\
\hline \multirow[t]{2}{*}{ Shapiro and Khemani (1987) } & Canada & 143 & $1972-76$ & GNE & + & ++ & \\
\hline & & & & GNX & 0 & 0 & Displacement \\
\hline \multirow[t]{4}{*}{ Khemani and Shapiro (1988) } & Canada & 143 & $1972-76$ & GNE & ++ & ++ & Specialist entry \\
\hline & & & & GNE & 0 & + & Diversifying entry \\
\hline & & & & GNE & ++ & ++ & Domestic entry \\
\hline & & & & GNE & + & 0 & Foreign entry \\
\hline Acs and Audretsch (1989a) & USA & 247 & $1978-80$ & NRE & $0 /+$ & ++ & Small entry \\
\hline Acs and Audretsch (1989b) & USA & 238 & $1976-82$ & GRE & 0 & ++ & \\
\hline $\begin{array}{l}\text { Chappell, Kimenyi and Mayer } \\
\text { (1990) }\end{array}$ & USA & 330 & $1972-77$ & NNE & $0 /++$ & ++ & \\
\hline Jeong and Masson (1990) & Korea & 62 & $1976-81$ & NRE & 0 & 0 & \\
\hline Kessides (1990) & USA & 250 & $1972-82$ & NNE & $*$ & ++ & \\
\hline
\end{tabular}


TABLE III. Continued

\begin{tabular}{|c|c|c|c|c|c|c|c|}
\hline Study & Country & Ind & Period & Mea & Prof & Grow & Remarks \\
\hline Dunne and Roberts (1991) & USA & 386 & $1963-82$ & $\begin{array}{l}\text { GRE } \\
\text { GSE } \\
\text { GRX } \\
\text { GSX }\end{array}$ & $\begin{array}{l}++ \\
0 \\
++ \\
+\end{array}$ & $\begin{array}{l}++ \\
++ \\
-- \\
--\end{array}$ & \\
\hline Flynn (1991) & USA & 298 & $1978-84$ & GNX & -- & - & Displacement \\
\hline Geroski (1991a) & UK & 95 & $1983-84$ & $\begin{array}{l}\text { NSE } \\
\text { NSE }\end{array}$ & $\begin{array}{l}+ \\
0\end{array}$ & - & $\begin{array}{l}\text { Domestic entry } \\
\text { Foreign entry }\end{array}$ \\
\hline Mata (1991) & Portugal & 73 & $1982-86$ & $\begin{array}{l}\text { GNE } \\
\text { GNE }\end{array}$ & $\begin{array}{l}+ \\
0\end{array}$ & $\begin{array}{l}0 \\
+\end{array}$ & $\begin{array}{l}\text { Small entry } \\
\text { Large entry }\end{array}$ \\
\hline Schwalbach (1991) & Germany & 79 & $1983-85$ & GRE & + & + & \\
\hline $\begin{array}{l}\text { Sleuwaegen and } \\
\text { Dehandschutter (1991) }\end{array}$ & Belgium & 109 & $1980-84$ & $\begin{array}{l}\text { GRE } \\
\text { GRX }\end{array}$ & $\begin{array}{l}+ \\
-\end{array}$ & $\begin{array}{l}++ \\
--\end{array}$ & $\begin{array}{l}\text { Replacement } \\
\text { Displacement }\end{array}$ \\
\hline Von der Fehr (1991) & Norway & 97 & $1981-85$ & GNE & ++ & 0 & $\begin{array}{l}\text { Specialist entry } \\
\text { Replacement } \\
\text { Diversifying entry } \\
\text { Replacement }\end{array}$ \\
\hline Yamawaki (1991) & Japan & 135 & $1980-84$ & NRE & $0 /+$ & $t+$ & \\
\hline $\begin{array}{l}\text { Rosenbaum and Lamort } \\
\text { (1992) }\end{array}$ & USA & 213 & $1972-82$ & $\begin{array}{l}\text { GRE } \\
\text { GRX }\end{array}$ & $\begin{array}{l}++ \\
0\end{array}$ & ++ & $\begin{array}{l}\text { Replacement } \\
\text { Displacement }\end{array}$ \\
\hline Mata $(1993)$ & Portugal & 68 & $1982-86$ & $\begin{array}{l}\text { GNE } \\
\text { GNE }\end{array}$ & $\begin{array}{l}0 \\
0\end{array}$ & $\begin{array}{l}+ \\
0\end{array}$ & $\begin{array}{l}\text { Specialist entry } \\
\text { Diversifying entry }\end{array}$ \\
\hline Rosenbaum (1993) & USA & 241 & $1972-82$ & NRE & ++ & ++ & \\
\hline Audretsch and Acs (1994) & USA & 117 & $1976-86$ & GNE & $\mathrm{n}$ & 0 & \\
\hline $\begin{array}{l}\text { Santarelli and Sterlacchini } \\
\text { (1994) }\end{array}$ & Italy & 21 & $1986-89$ & GRE & 0 & ++ & \\
\hline Wagner (1994) & Germany & 29 & $1979-88$ & GEE & $0 /--$ & $+/++$ & Small entry \\
\hline
\end{tabular}

Note: Measures of entry and exit, GDE = Gross Dummy Entry ( 1 in case of entry else 0$)$; GEE $=$ Gross Employment share of Entry; GEX = Gross Employment share of exit; GNE = Gross Number of Entering firms; GNX = Gross Number of exiting firms; GRE = Gross Rate of Entry; GRX = Gross Rate of exit; GSE = Gross Sales (or production) share of Entry; GSX = Gross Sales (or production) share of exit; NNE = Net Number of Entering firms; NRE = Net Rate of Entry; NSE $=$ Net Sales share of Entry.

Effects of Prof(itability) and Grow(th), $--t$-value below $-2.5 ;-t$-value betwecn -2.5 and $-1.5 ; 0 t$-value between -1.5 and $+1.5 ;+t$-value between +1.5 and $+2.5 ;+t t$-value above +2.5 ; $\mathrm{n}$ not incorporated.

Displacement: Entry is determinant of exit; Replacement: Exit is determinant of entry; Mea = measure of entry or exit; Ind = number of industries.

* Kessides $(1986,1990)$ estimates a non-linear specification, leading to industry-dependent effects of profitability on entry.

demand growth on entry and exit is investigated by the variable DCS: the growth rate of real consumer expenditure on goods primarily sold in the shoptype. The variables PMI, PRI and DCS are one period lagged to adjust for the time period 
TABLE IV. Summary of empirical studies listed in Table III

\begin{tabular}{|c|c|c|c|c|c|c|c|c|c|c|c|c|}
\hline & \multicolumn{6}{|c|}{ Effect of profitability } & \multicolumn{6}{|c|}{ Effect of growth } \\
\hline & -- & - & 0 & + & ++ & Total & -- & - & 0 & + & ++ & Total \\
\hline Gross Entry & 1 & 0 & 14 & 11 & 9 & 35 & 0 & 0 & 9 & 10 & 18 & 37 \\
\hline Gross Exit & 1 & 3 & 3 & 2 & 1 & 10 & 4 & 1 & 4 & 0 & 0 & 9 \\
\hline New Entry & 0 & 1 & 4 & 6 & 2 & 13 & 0 & 1 & 4 & 1 & 12 & 18 \\
\hline
\end{tabular}

Note: See note to Table III. In case the study has presented evidence for both a significant and a non-significant effect (eight cases for the effect of profitability and two cases for the effect of growth), we have chosen for the significant one.

necessary for (potential) entrepreneurs to react to incentives. See Table II for the correlations between these three measures and the entry and exit rates.

We also incorporate $\mathrm{UN}$, the level of unemployment (in 1,000,000 persons), and the change in this variable (DUN). ${ }^{5}$ A high level of unemployment or an increase in unemployment may have a positive effect on entry. Workers who are or become unemployed may consider becoming self-employed in the retail sector. Retailing is a comparably simple entrepreneurial activity which requires only a limited financial investment. Also, it may have a negative effect on exit. High levels of unemployment or strong increases in this level may deter shopkeepers to exit because of the unfavourable conditions on the labour market. Being or becoming unemployed can therefore be interpreted as incentive to enter and disincentive to exit. However, one has to be careful when interpreting the effect of the (change in the) level of unemployment because unemployment data do not always provide an adequate picture of the tension on the labour market and because the great majority of unemployed never consider a new firm start-up or let alone reach the stage of starting their own retail business. The variables UN and DUN are one period lagged in the entry equation. We assume that shopkeepers' exit decisions are affected by contemporaneous labour market conditions but that there is a lag between being or becoming unemployed and starting a retail venture.

Three indicators of the level of entry and exit barriers are considered. First, the degree of franchising, DF, is included. This variable is defined by the number of franchisees divided by the total number of firms. Entry by an independent firm may be expected to be less attractive in a shoptype in which franchising has proved a successful instrument of market penetration. The importance of the degree of franchising as entry barrier may however be limited because the viability of market niches is seldomly affected by an increase in the degree of franchising. An important feature of franchising is a high degree of similarity of the shops and franchisees therefore may lack the specialization needed for successful exploitation of market niches. The extent to which franchising may be considered to be an exit

${ }^{5}$ See Hudson (1989) and Storey (1991) for investigations into the effect of unemployment on entry and exit. 
barrier is also uncertain. Small independents will be confronted by competition from franchisees. The franchiser may however provide independents who threaten to succumb to this competitive pressure the opportunity of becoming franchisees as well. That is, firms which suffer from the competition by franchisees may very well profit from the competition between franchisers to obtain new outlets. A second indicator of the level of entry and exit barriers is small store presence, SSP. A large small store presence indicates that entry and exit barriers are low because a high sales volume does not seem to be prerequisite for entrepreneurial activity. We define SSP as the ratio of sales by firms with less than 10 employees to total sales. A positive effect of small store presence on entry and on exit is expected. Acs and Audretsch (1989a) however find for U.S. manufacturing that small firms do not tend to enter those industries in which there is already a considerable presence of small firms. They claim that 'flexible specialization' may have enabled small firms to enter and exist in markets where they previously would have experienced severe scale disadvantages. A third indicator of the level of entry and exit barriers is floorspace requirement. Retail business which needs extensive floorspace, FS, may be more difficult to set up. High floorspace requirement indicates high financial investments and problems in finding an appropriate establishment. This constitutes an important entry barrier in retailing. It may also be considered an exit barrier because the amount of floorspace is often closely linked to high investments in inventory and long tenancy agreements. ${ }^{6}$ We measure floorspace in 10,000 square meters. The variables DF, SSP and FS are all one period lagged in the entry equation. We assume that a decision to enter is based on market characteristics of one year before, while a decision to exit is affected by contemporaneous market characteristics.

\section{Effects and Estimation of Displacement and Replacement}

Some recent studies, like Rosenbaum and Lamort (1992) and Sleuwaegen and Dehandschutter (1991), consider the effects of displacement and replacement. Displacement is the positive effect of entry on exit. There are two possible causes for this effect. First, new entry may lead to stronger competitive pressures which lcad to exit (cntry 'forces' exit). Sccond, independents who seriously consider to exit may wait for new entrants to take over their business. Replacement is the positive effect of exit on entry. There are again two possible causes. First, exit may provide additional market room for (potential) entrepreneurs to enter (exit 'allows' entry). Second, entrepreneurs may wait to enter until they are offered the opportunity to take over a shop (and its clientele).

Displacement implies that entry is an explanatory variable in the exit equation, while replacement implies that exit is an explanatory variable in the entry equation. In case exit (entry) can be treated as exogenous to the entry (exit) equation we use

${ }^{6}$ Caves and Porter (1976) provide evidence, using a sample of 310 businesses for the 1970-1973 period, that high fixed investments prevent low-return businesses to exit. 
the Seemingly Unrelated Relations (SUR) estimation technique. If however entry and exit are simultaneously determined, i.e. exit (entry) is endogenous to the entry (exit) equation, we choose a simultaneous equations estimation technique like Three Stage Least Squares (3SLS). The question now is whether exit (entry) can be treated as exogenous versus endogenous in the entry (exit) equation. In case of exogeneity the equations can be interpreted as reduced form equations. This implies that the entry and exit rates cannot be expressed as functions of market incentives and barriers only.

We test the null hypothesis of exogeneity of the exit (entry) rate in the entry (exit) equation in two ways. ${ }^{7}$ Using the Hausman approach (see e.g. Godfrey (1988), sec. 1.6 or MacKinnon (1992), sec. 9)) we estimate the model using Three Stage Least Squares (3SLS) and using SUR. Both estimation techniques are consistent under the null hypothesis of exogeneity, but SUR is the more efficient one. SUR is however not consistent under the alternative hypothesis of endogeneity, while 3SLS is. The Hausman test statistic is defined as $\left(\hat{\alpha}_{3 \mathrm{SLS}}-\hat{\alpha}_{\mathrm{SUR}}\right)^{\prime}\left(S_{3 \mathrm{SLS}}-S_{\mathrm{SUR}}\right)^{-1}\left(\hat{\alpha}_{3 \mathrm{SLS}}-\right.$ $\left.\hat{\alpha}_{\text {SUR }}\right)$, where $\hat{\alpha}_{3 S L S}$ and $\hat{\alpha}_{3 S U R}$ stand for the parameter vector estimators using 3SLS and SUR, respectively. The matrices $S_{3 \text { SLS }}$ and $S_{\text {SUR }}$ are the corresponding estimators of the covariance matrices. ${ }^{8}$ The Hausman test statistic is asymptotically $\chi^{2}$-distributed under the null hypothesis with degrees of freedom equal to the number of elements of the parameter vector. Rosenbaum and Lamort (1992) use the Spencer-Berk test statistic (see Kmenta (1986), sec. 13.6). ${ }^{9}$ This test involves calculating exit's (entry's) expected value by regressing exit (entry) on all the predetermined variables in the system and by evaluating the estimated $t$-value of the coefficient of this expected value when included next to the observed exit (entry) using OLS estimation. Under the null hypothesis of exogeneity this value is $t$-distributed with degrees of freedom equal to the number of observations minus the number of variables in the model.

We also incorporate the one period lagged entry and exit rates in the model. The lagged exit rate $\left(\mathrm{EXIT}_{-1}\right)$ affects the entry rate when replacement is not immediate but taking place after one time period. We also expect the lagged entry rate ENTRY $_{-1}$ ) to have a positive effect on the entry rate. Gort and Konakayama (1982) argue that perceptions of profit opportunities are positively related to the successful experience of others in the market. Entrepreneurial activity may very well tend to be autocorrelated: the incidence of entry may stimulate (potential)

\footnotetext{
${ }^{7}$ MacKinnon (1992, p. 126) claims that one should not interpret these tests as tests on exogeneity. One really tests whether possible endogeneity causes SUR estimates to be inconsistent.

${ }^{8}$ The procedure runs into difficulties when $S_{3 S L S}-S_{\text {SUR }}$ is not positive definite, which is often the case in practice. We did not encounter this problem in any of the tests.

${ }^{9}$ Rosenbaum and Lamort (1992) report an insignificant Spencer-Berk exogeneity test statistic. This implies that exit (entry) can be treated as exogeneous to the entry (exit) equation in their sample. Their final conclusion is however incorrect: they claim that entry and exit do not appear to be causally related but that they are just part of the same market process. Exogeinity does however not imply that entry does not cause exit and vice versa. It implies that entry and exit are not simultaneously determined.
} 
entrepreneurs to consider entry as well. Gort and Konakayama refer to this as the demonstration effect. Similar arguments for the incorporation of the lagged entry and exit rate in the exit equation can be used. ${ }^{10}$

The empirical model (fixed effects included) to be investigated is:

$$
\begin{aligned}
\text { ENTRY }_{i t}= & a_{0 i}+a_{1} \mathrm{PMI}_{i, t-1}+a_{2} \mathrm{PRI}_{i, t-1}+a_{3} \mathrm{DCS}_{i, t-1}+a_{4} \mathrm{UN}_{t-1} \\
& +a_{5} \mathrm{DUN}_{t-1}+a_{6} \mathrm{DF}_{i, t-1}+a_{7} \mathrm{SSP}_{i, t-1}+a_{8} \mathrm{FS}_{i, t-1} \\
& +a_{9} \mathrm{EXIT}_{i t}+a_{10} \mathrm{EXIT}_{i, t-1}+a_{11} \mathrm{ENTRY}_{i, t-1}+\varepsilon_{1 i t}
\end{aligned}
$$

$$
\begin{aligned}
\operatorname{EXIT}_{i t}= & b_{0 i}+b_{1} \mathrm{PMI}_{i, t-1}+b_{2} \mathrm{PRI}_{i, t-1}+b_{3} \mathrm{DCS}_{i, t-1}+b_{4} \mathrm{UN}_{t} \\
& +b_{5} \mathrm{DUN}_{t}+b_{6} \mathrm{DF}_{i t}+b_{7} \mathrm{SSP}_{i, t}+b_{8} \mathrm{FS}_{i t} \\
& +b_{9} \mathrm{ENTRY}_{i t}+b_{10} \mathrm{ENTRY}_{i, t-1}+b_{11} \mathrm{EXIT}_{i, t-1}+\varepsilon_{2 i t}
\end{aligned}
$$

where ENTRY = Entry rate; EXIT = Exit rate; PMI = Profit divided by modal income; $\mathrm{PRI}=$ Profit divided by equity; $\mathrm{DCS}=$ Change in real consumer spending; $\mathrm{UN}=$ Number of unemployed; DUN = Change in the number of unemployed; DF $=$ Degree of franchising; $\mathrm{SSP}=$ Small store presence; $\mathrm{FS}=$ Floorspace requirement.

\section{Data and Empirical Results}

In this study a data-set of 23 Dutch shoptypes for the period 1981-1988 is used. This implies a total of 184 data-points. The source of the data is an ongoing panel of independent, mainly small Dutch retailers called Bedrijfssignaleringssysteem (interfirm comparison system) which is operated by the EIM Small Business Research and Consultancy (EIM) in Zoetermeer. ${ }^{11}$ On average a data-point is computed using observations from about seventy individual retail stores. The consumer spending and modal income data are from the Central Bureau of Statistics (CBS) in Voorburg, ${ }^{12}$ unemployment data were retrieved from the UN Monthly Bulletin

${ }^{10}$ In their study of the interaction of entry and exit rates, Johnson and Parker (1994) also investigate displacement, replacement and demonstration effects. They use a different terminology for these effects, viz. competition and multiplier effects. They apply a vector autoregression approach without exogenous variables to entry and exil rates in the United Kingdom in the 1980s and find support for the existence of both these effects.

${ }^{11}$ In Carree and Thurik $(1994,1995)$ a more extensive data-set is used of 36 shoptypes covering a longer time period. However, the limited availability of data of the degree of franchising and of small store presence confines our data-set to 23 shoptypes for the 1981-1988 period.

12 There were no data available on small store presence for three shoptypes: "bakers", "confectioners" and "pet shops". These shoptypes consist of small firms (less than 10 employees) for nearly $100 \%$. Small store presence is taken to be unity in every period for these shoptypes. Data on small store presence were available for four shoptypes for 1988 only: "greengrocers", "florists", "fish shops" and "tobacco shops". In these shoptypes small firms accounted for at least for $85 \%$ of the sales in that year. Small store presence in the years $1980-1987$ is taken to be equal to the 1988-level. 
of Statistics and data on entry and exit of retail establishments were gathered by the Central Registration Office (CRK) in The Hague. Data on the total number of franchisees were available only for 1980,1982 and 1988. We used an interpolation for the intermediate years.

Table V presents the empirical results with fixed effects (shoptype dummies) assumed in all models (use is made of the SAS-module SYSLIN). The first two columns contain the estimation results when displacement and replacement effects are not taken into account $\left(a_{9}=a_{10}=a_{11}=b_{9}=b_{10}=b_{11}=0\right)$. We incorporate the displacement and replacement effect in the next two columns by considering exit (entry) to be endogenous to the entry (exit) equation $\left(a_{10}=a_{11}=b_{10}=b_{11}=0\right.$ ) We proceed to test whether SUR estimation is viable by using the Hausman and Spencer-Berk test statistics. Both statistics support the null hypothesis of the entry rate to be exogenous to the exit equation and vice versa. The Hausman statistics are 10.204 for the entry equation ( $p$-value is 0.33 ) and 4.994 for the exit equation ( $p$-value is 0.83), while the Spencer-Berk statistics are 0.564 ( $p$-value is 0.57 ) and -1.377 ( $p$-value is 0.17 ), respectively. Columns five and six contain the results when the model is re-estimated using SUR (again $a_{10}=a_{11}=b_{10}=b_{11}=0$ )). In the next columns we present estimation results when the one period lagged entry and exit rates are incorporated into the model. The Hausman and Spencer-Berk test statistics again point to (pair-wise) exogeneity of the entry and exit rate. The Hausman statistics are 10.530 for the entry equation ( $p$-value is 0.48 ) and 2.430 for the exit equation ( $p$-value is 0.99 ), while the Spencer-Berk statistics are 0.889 ( $p$-value is 0.37 ) and -1.265 ( $p$-value is 0.20 ), respectively. Therefore, we also present estimation results using SUR in the last two columns.

The SUR estimation results give strong support for the positive effects of profitability and demand growth on entry and the negative effects of these variables on exit. Entry and exit rates in retailing seem to be more sensitive to market incentives than in manufacturing when considering the mixed results for manufacturing industries (see Section 2). The surplus of profit over modal income (PMI-1) and the growth rate of real consumer spending for goods primarily sold in the shoptype $\left(\mathrm{DCS}_{-1}\right)$ have positive and significant effects on entry and negative and significant effects on exit. See Table I for the average values of PMI ${ }_{-1}$ and DCS $_{-1}$ in the 23 shoptypes. Return on investment (PRI-1) has no effect on either entry or exit rates. This indicates that (potential) shopkeepers place higher value on the reward for their labour input than on the reward for their capital investments when considering entry or exit.

The level of unemployment (UN) does not have the expected positive effect on the cntry rate nor the negative effect on the exit rate. This may be a consequence of the level of unemployment acting as a business cycle indicator next to the shoptypespecific market growth (DCS). The change in the level of unemployment (DUN) does however have the expected effects. This variable may be a more reliable indicator of opportunities on the labour market during the 1980s than the level of unemployment because of the consistent high number of structurally unemployed 
TABLE V. Empirical results for entry and exit models

\begin{tabular}{|c|c|c|c|c|c|c|c|c|c|c|}
\hline \multirow[b]{2}{*}{ Variable } & \multicolumn{2}{|l|}{ SUR } & \multicolumn{2}{|l|}{ 3SLS } & \multicolumn{2}{|l|}{ SUR } & \multicolumn{2}{|l|}{ 3SLS } & \multicolumn{2}{|l|}{ SUR } \\
\hline & ENTRY & EXIT & ENTRY & EXIT & ENTRY & EXIT & ENTRY & EXIT & ENTRY & EXIT \\
\hline PMI_1 & $\begin{array}{l}0.019^{*} \\
(2.4)\end{array}$ & $\begin{array}{c}-0.012 \\
(2.0)\end{array}$ & $\begin{array}{l}0.031^{*} \\
(4.8)\end{array}$ & $\begin{array}{c}-0.012 \\
(1.7)\end{array}$ & $\begin{array}{l}0.028^{*} \\
(4.7)\end{array}$ & $\begin{array}{c}-0.019^{*} \\
(3.9)\end{array}$ & $\begin{array}{l}0.029^{*} \\
(4.5)\end{array}$ & $\begin{array}{c}-0.006 \\
(0.6)\end{array}$ & $\begin{array}{l}0.026^{*} \\
(4.5)\end{array}$ & $\begin{array}{c}-0.017^{*} \\
(3.5)\end{array}$ \\
\hline PRI_1 & $\begin{array}{l}0.003 \\
(0.2)\end{array}$ & $\begin{array}{l}0.006 \\
(0.4)\end{array}$ & $\begin{array}{c}-0.009 \\
(0.6)\end{array}$ & $\begin{array}{l}0.004 \\
(0.3)\end{array}$ & $\begin{array}{c}-0.008 \\
(0.5)\end{array}$ & $\begin{array}{c}0.009 \\
(0.7)\end{array}$ & $\begin{array}{c}-0.012 \\
(0.8)\end{array}$ & $\begin{array}{l}0.002 \\
(0.1)\end{array}$ & $\begin{array}{c}-0.011 \\
(0.8)\end{array}$ & $\begin{array}{c}-0.010 \\
(0.8)\end{array}$ \\
\hline $\mathrm{DCS}_{-1}$ & $\begin{array}{l}0.026 \\
(0.7)\end{array}$ & $\begin{array}{c}-0.042 \\
(1.3)\end{array}$ & $\begin{array}{l}0.088^{*} \\
(2.7)\end{array}$ & $\begin{array}{c}-0.045 \\
(1.3)\end{array}$ & $\begin{array}{l}0.087^{*} \\
(3.0)\end{array}$ & $\begin{array}{l}-0.080^{*} \\
(3.1)\end{array}$ & $\begin{array}{l}0.088^{*} \\
(2.5)\end{array}$ & $\begin{array}{c}-0.054 \\
(1.5)\end{array}$ & $\begin{array}{l}0.085^{*} \\
(3.0)\end{array}$ & $\begin{array}{c}-0.082^{*} \\
(3.3)\end{array}$ \\
\hline $\mathrm{UN}_{(-1)}$ & $\begin{array}{l}0.010 \\
(1.1)\end{array}$ & $\begin{array}{l}0.028^{*} \\
(2.8)\end{array}$ & $\begin{array}{l}-0.014 \\
(1.6)\end{array}$ & $\begin{array}{l}0.022^{*} \\
(2.2)\end{array}$ & $\begin{array}{l}-0.017^{*} \\
(2.3)\end{array}$ & $\begin{array}{l}0.013 \\
(1.7)\end{array}$ & $\begin{array}{c}-0.013 \\
(1.7)\end{array}$ & $\begin{array}{l}0.014 \\
(1.4)\end{array}$ & $\begin{array}{c}-0.015^{*} \\
(2.2)\end{array}$ & $\begin{array}{l}0.011 \\
(1.4)\end{array}$ \\
\hline $\operatorname{DUN}_{(-1)}$ & $\begin{array}{l}0.043^{*} \\
(2.9)\end{array}$ & $\begin{array}{c}-0.011 \\
(0.9)\end{array}$ & $\begin{array}{l}0.032^{*} \\
(2.3)\end{array}$ & $\begin{array}{c}-0.018 \\
(1.4)\end{array}$ & $\begin{array}{l}0.023^{*} \\
(2.1)\end{array}$ & $\begin{array}{l}-0.025^{*} \\
(2.4)\end{array}$ & $\begin{array}{l}0.036^{*} \\
(2.5)\end{array}$ & $\begin{array}{c}-0.008 \\
(0.4)\end{array}$ & $\begin{array}{l}0.023^{*} \\
(2.1)\end{array}$ & $\begin{array}{c}-0.023^{*} \\
(2.2)\end{array}$ \\
\hline $\mathrm{DF}_{(-1)}$ & $\begin{array}{l}0.195^{*} \\
(2.6)\end{array}$ & $\begin{array}{l}0.141^{*} \\
(2.7)\end{array}$ & $\begin{array}{l}0.042 \\
(0.7)\end{array}$ & $\begin{array}{c}0.101 \\
(1.7)\end{array}$ & $\begin{array}{l}0.024 \\
(0.4)\end{array}$ & $\begin{array}{l}0.019 \\
(0.4)\end{array}$ & $\begin{array}{l}0.060 \\
(1.0)\end{array}$ & $\begin{array}{l}0.092 \\
(1.2)\end{array}$ & $\begin{array}{l}0.039 \\
(0.7)\end{array}$ & $\begin{array}{l}0.009 \\
(0.2)\end{array}$ \\
\hline $\operatorname{SSP}_{(-1)}$ & $\begin{array}{l}-0.106 \\
(1.1)\end{array}$ & $\begin{array}{c}0.036 \\
(0.5)\end{array}$ & $\begin{array}{c}-0.138 \\
(1.8)\end{array}$ & $\begin{array}{l}0.049 \\
(0.7)\end{array}$ & $\begin{array}{c}-0.160^{*} \\
(2.2)\end{array}$ & $\begin{array}{l}0.130^{*} \\
(2.4)\end{array}$ & $\begin{array}{c}-0.086 \\
(1.1)\end{array}$ & $\begin{array}{l}0.020 \\
(0.2)\end{array}$ & $\begin{array}{c}-0.105 \\
(1.5)\end{array}$ & $\begin{array}{l}0.091 \\
(1.6)\end{array}$ \\
\hline $\mathrm{FS}_{(-1)}$ & $\begin{array}{l}-0.888^{*} \\
(4.2)\end{array}$ & $\begin{array}{c}-0.309^{*} \\
(2.0)\end{array}$ & $\begin{array}{l}-0.654^{*} \\
(3.1)\end{array}$ & $\begin{array}{c}-0.464 \\
(1.5)\end{array}$ & $\begin{array}{c}-0.379^{*} \\
(2.4)\end{array}$ & $\begin{array}{l}0.023 \\
(0.2)\end{array}$ & $\begin{array}{l}-0.518^{*} \\
(2.6)\end{array}$ & $\begin{array}{c}-0.508 \\
(1.3)\end{array}$ & $\begin{array}{c}-0.309 \\
(1.9)\end{array}$ & $\begin{array}{c}-0.033 \\
(0.2)\end{array}$ \\
\hline EXIT & & & $\begin{array}{l}1.060^{*} \\
(5.1)\end{array}$ & & $\begin{array}{l}1.108^{*} \\
(17.5)\end{array}$ & & $\begin{array}{l}0.992^{*} \\
(4.3)\end{array}$ & & $\begin{array}{l}1.031^{*} \\
(14.9)\end{array}$ & \\
\hline ENTRY & & & & $\begin{array}{l}0.215 \\
(0.9)\end{array}$ & & $\begin{array}{l}0.720^{*} \\
(16.0)\end{array}$ & & $\begin{array}{l}0.040 \\
(0.1)\end{array}$ & & $\begin{array}{l}0.700^{*} \\
(13.6)\end{array}$ \\
\hline EXIT_-1 $_{1}$ & & & & & & & $\begin{array}{c}-0.158 \\
(1.3)\end{array}$ & $\begin{array}{l}0.336^{*} \\
(2.6)\end{array}$ & $\begin{array}{c}-0.165 \\
(1.8)\end{array}$ & $\begin{array}{l}0.205^{*} \\
(2.6)\end{array}$ \\
\hline ENTRY -1 & & & & & & & $\begin{array}{l}0.249^{*} \\
(2.9)\end{array}$ & $\begin{array}{l}0.115 \\
(0.6)\end{array}$ & $\begin{array}{l}0.263^{*} \\
(3.5)\end{array}$ & $\begin{array}{c}-0.159^{*} \\
(2.4)\end{array}$ \\
\hline$F_{\mathrm{FE}}$ & $16.508^{*}$ & $12.980^{*}$ & $2.797^{*}$ & $1.670^{*}$ & $7.750^{*}$ & $5.508^{*}$ & $1.953^{*}$ & 0.907 & $3.494^{*}$ & $2.733^{*}$ \\
\hline$r$ & 0.848 & 0.830 & 0.916 & 0.880 & 0.911 & 0.894 & 0.924 & 0.875 & 0.920 & 0.900 \\
\hline System- $R^{2}$ & 0.6 & 664 & 0.7 & 738 & 0.9 & 945 & 0.7 & 791 & & 940 \\
\hline$\chi_{\text {Hausman }}^{2}$ & & & 10.204 & 4.994 & & & 10.530 & 2.430 & & \\
\hline$t_{\text {Spencer-Berk }}$ & & & 0.564 & -1.377 & & & 0.889 & -1.265 & & \\
\hline
\end{tabular}

Note: All models are estimated with fixed effects. Numbers in parentheses are $t$-statistics. Coefficients which are significant at a $5 \%$-significance level are denoted by ${ }^{*}$. The test statistics $F_{\mathrm{FE}}, \chi_{\mathrm{Hausman}}^{2}$ and $t_{\text {Spencer-Rerk }}$ stand for the $F$-test on the hypothesis of the absence of shoptype specific effects (fixed effects) and the Hausman $\chi^{2}$-test and Spencer-Berk $t$-test on the hypothesis of exogeneity of ENTRY in the exit equation and of EXIT in the entry equation. The coefficient $r$ stands for the estimated correlation between the observed entry (exit) rate and the estimated entry (exit) rate. The variables UN, DUN, DF, SSP and FS are one period lagged only for the entry equation.

in the Netherlands during that period. Workers who have only recently become unemployed may also be more able and motivated to use self-employment as an alternative to being unemployed than people who have had no working experience for a longer time period. The results show that an increase in the number of unemployed appears to lead to more entry while it seems to prevent exit. 
The degree of franchising (DF) has no significant effects on entry or exit when the displacement and replacement effects are included in the model. The positive effect of the degree of franchising on the entry and exit rate when displacement and replacement are not taken into consideration, does indicate that part of the replacement and displacement process originates from the growing market penetration of franchisers. Small store presence (SSP) has a significant effect on the entry and exit rate only in case of SUR-estimation with lagged dependent variables excluded. The presence of many small stores appears not to be attractive to new entrants, which is in accordance with results found by Acs and Audretsch (1989a) for U.S. manufacturing. At the same time we do find that the exit rate is higher, ceteris paribus, in shoptypes dominated by small stores. The net exit in shoptypes dominated by small stores leads to the general decline of small store presence in retailing. ${ }^{13}$ The floorspace requirement (FS) has a significant negative effect on entry, while it has no significant effect on exit. One can conclude that floorspace requirement (or more generally investment requirement) obstructs entry.

The effects of many other entry and exit barriers are adjusted for by the inclusion of fixed effects. The value and significance of the shoptype dummy-coefficients therefore may provide some additional information on the (relative) ease of entry and exit over the shoptypes. One can divide the 23 shoptypes into 9 shoptypes with relatively high requirements of professional skills and 14 shoptypes with only limited requirements. The first group consists of "supermarkets with butcher's shop", "butchers", "bakers", "confectioners", "liquor stores", "bicycles", "photographer's shops", "watches, gold, silver" and "druggists". In case of SUR estimation without displacement and replacement effects the mean dummy in the entry equation is 0.122 for this first group, while it is 0.185 for the other 14 shoptypes ( $t$-test on equality of means: -2.21 ). For the mean dummy in the exit equation the figures are 0.043 and 0.076 ( $t$-test: -1.57 ). In case of SUR estimation with lagged dependent variables included the mean dummy in the entry equation is 0.046 for the first group and 0.064 for the second group ( $t$-test: -1.56$)$. The respective mean dummies in the exit equation are -0.027 and -0.028 ( $t$-test: 0.07 ). That is, requirements of professional skills appear to reduce entry rates (but not exit rates) and therefore may slow down adjustment processes in retailing.

The coefficient of the exit rate incorporated in the entry equation is very close to unity, independent of whether 3SLS or SUR is used as estimation technique. Rosenbaum and Lamort (1992) also found this result for U.S. manufacturing using the SUR estimation technique. If no information on incentives or barriers would be available one could consider the exit rate to be a good predictor of the entry rate in a shoptype. The extent to which the entry rate exceeds the exit rate, i.e. the extent to which net entry is positive, depends on the attractiveness of the shoptype and barriers impeding new entrants to occupy the market room created by exit. There is

${ }^{13}$ See Carree, Potjes and Thurik (1993) for a study into the determinants of the declining small store presence found in Japanese retailing. See Nooteboom (1986) for a general discussion of the 'ousting of smallness' in retailing. 
support for the demonstration effect: the lagged entry rate has a significant positive effect on the present period's entry rate.

The treatment of the entry rate as endogenous or exogenous variable, has an important impact on the effect of this variable in the exit equation: the coefficient becomes significant in case SUR is used, while it is not significant using the 3SLS estimation technique. The Hausman and Spencer-Berk test statistics provide support for the use of the SUR estimation technique. This is evidence for entry to influence exit while they are not simultaneously determined. The lagged exit rate has a significant positive effect on the present period's exit rate. This could again be related to a demonstration effect. Firms that change their range of activities, shifting to another shoptype, may be followed by competitors.

\section{Conclusions}

The determinants of entry and exit in retailing are the subject of research in this paper. Retailing is an interesting testing area for these determinants not only because of its importance in the economy but also because of its presumed sensitivity to market incentives due to the limited amount of investments and skills needed when compared to other sectors. We find lagged profitability and lagged market growth in this sector to have a significant positive effect on entry and a significant negative effect on exit. Growing unemployment also seems to stimulate entry and to obstruct exit. Evidence is found for shoptypes dominated by small stores to have lower entry rates and higher exit rates. The variable describing the extent of floorspace requirement has a significant negative effect on the entry rate suggesting that it acts as an impediment to new firm entry. We also find evidence for the entry rate to be lower in shoptypes with relatively high requirements of professional skills. This provides support for the recent decision made by the Dutch Ministry of Economic Affairs to abolish a wide variety of legal requirements in retailing in order to improve dynamic market efficiency.

There is strong statistical support for the incorporation of exit (entry) as determinant of entry (exit). Shoptypes with high entry rates also have high exit rates. Such high turnover may however not only result from low entry (exit) barriers, but also from entrants replacing or displacing exiting firms. We find evidence for these displacement and replacement processes. There is however no evidence of simultaneity of the entry and exit rates. This implies that Equations (1) and (2) can be interpreted as reduced form equations. As a consequence, the entry and exit rates cannot be expressed as functions of market incentives and barriers only. Studies which do not take into account the separate influence of entry on exit, i.e. displacement, and the separate influence of exit on entry, i.e. replacement, will therefore suffer from an omitted variable bias. 


\section{References}

Acs, Z. J. and Audretsch, D. B. (1989a) 'Small-firm Entry in US Manufacturing', Economica, 56, $255-265$.

Acs, Z. J. and Audretsch, D. B. (1989b) 'Births and Firm Size', Southern Economic Journal, 56, $467-475$.

Audretsch, D. B. and Acs, Z. J. (1994) 'New-Firm Startups, Technology, and Macroeconomic Fluctuations', Small Business Economics, 6, 439-449.

Baldwin, J. R. and Gorecki, P. K. (1987) 'Plant Creation versus Plant Acquisition', International Journal of Industrial Organization, 5, 27-41.

Beesley, M. E. and Hamilton, R. T. (1984) 'Small Firms' Seedbed Role and the Concept of Turbulence', Journal of Industrial Economics, 33, 217-231.

Bode, B. (1990) Studies in Retail Pricing, Ph.D.-thesis, Rotterdam.

Carree, M. A., Potjes, J. C. A., and Thurik, A. R. (1993) 'Small Store Presence in Japan',Economics Letters, 41, 329-334.

Carree, M. and Thurik, R. (1994) 'The Dynamics of Entry, Exit and Profitability: An Error Correction Approach for the Retail Industry', Small Business Economics, 6, 107-116.

Carree, M. and Thurik, R. (1995) 'Profitability and Number of Firms: Their Dynamic Interaction in Dutch Retailing', in: A. van Witteloostuijn (ed.), Market Evolution: Competition and Cooperation, Studies in Industrial Organization, Vol. 20, Boston.

Caves, R. E. and Porter, M. E. (1976) 'Barriers to Exit', in: R. T. Masson and P. D. Qualls (eds.), Essays on Industrial Organization in Honor of Joe S. Bain, Cambridge.

Chappell, W. F., Kimenyi, M. S., and Mayer, W. J. (1990) 'A Poisson Probability Model of Entry and Market Structure with an Application to U.S. Industries during 1972-77', Southern Economic Journal, 56, 918-927.

Creedy, J. and Johnson, P. S. (1983) 'Firm Formation in Manufacturing Industry', Applied Economics, $15,177-185$.

Duetsch, L. L. (1975) 'Structure, Performance, and the Net Rate of Entry into Manufacturing Industries', Southern Economic Journal, 41, 450-456.

Dunne, T. and Roberts, M. J. (1991) 'Variation in Producer Turnover across US Manufacturing Industries', in: P. A. Geroski and J. Schwalbach (eds.), Entry and Market Contestability: An International Comparison, Oxford.

Dunne, T., Roberts, M. J., and Samuelson, L. (1988) 'Patterns of Firm Entry and Exit in U.S. Manufacturing Industries', RAND Journal of Economics, 19, 495-515.

Eaton, B. C. and Lipsey, R. G. (1980) 'Exit Barriers Are Entry Barriers: The Durability of Capital as a Barrier to Entry', BELL Journal of Economics, 11, 721-729.

EIM (1991) Kleinschalig Ondernemen 1991, Zoetermeer.

Flynn, J. E. (1991) 'The Determinants of Exit in an Open Economy', Small Business Economics, 3, 225-232.

Geroski, P. A. (1991a) 'Domestic and Foreign Entry in the United Kingdom: 1983-1984', in: P. A. Geroski and J. Schwalbach (eds.), Entry and Market Contestability: An International Comparison, Oxford.

Geroski, P. A. (1991b) Market Dynamics and Entry, Oxford.

Geroski, P. A. and Jacquemin, A. (1985) 'Industrial Change, Barriers to Mobility, and European Industrial Policy', Economic Policy, 1, 169-204.

Godfrey, L. G. (1988) Misspecification Tests in Econometrics, Cambridge.

Gorecki, P. K. (1975) 'The Determinants of Entry by New and Diversifying Enterprises in the UK Manufacturing Sector 1958-1963: Some Tentative Results', Applied Economics, 7, 139-147.

Gorecki, P. K. (1976) 'The Determinants of Entry by Domestic and Foreign Enterprises in Canadian Manufacturing Industries: Some Comments and Empirical Results', Review of Economics and Statistics, 58, 481-488.

Gort, M. and Konakayama, A. (1982) 'A Model of Diffusion in the Production of an Innovation', American Economic Review, 72, 1111-1120.

Hamilton, R. T. (1985) 'Interindustry Variation in Gross Entry Rates of 'Independent' and 'Dependent' Businesses', Applied Economics, 17, 271-280. 
Hause, J. C. and Du Rietz, G. (1984) 'Entry, Industry Growth, and the Micro-dynamics of Industry Supply', Journal of Political Economy, 92, 733-757.

Herck, G. van (1984) 'Entry, Exit and Profitability', Managerial and Decision Economics, 5, 25-31.

Highfield, R. and Smiley, R. (1987) 'New Business Starts and Economic Activity: An Empirical Investigation', International Journal of Industrial Organization, 5, 51-66.

Hilke, J. C. (1984) 'Excess Capacity and Entry: Some Empirical Evidence', Journal of Industrial Economics, 33, 233-240.

Hirschey, M. (1981) 'The Effect of Advertising on Industrial Mobility, 1947-72',Journal of Business, 54, 329-339.

Hopenhayn, H. A. (1992) 'Entry, Exit, and Firm Dynamics in Long Run Equilibrium', Econometrica, 60, 1127-1150.

Hudson, J. (1989) 'The Birth and Death of Firms', Quarterly Review of Economics and Business, 29, 68-86.

Jeong, K. Y. and Masson, R. T. (1990) 'Market Structure, Entry, and Performance in Korea', Review of Economics and Statistics, 72, 455-462.

Johnson, P. and Parker, S. (1994) 'The Interrelationships Between Births and Deaths', Small Business Economics, 6, 283-290.

Jovanovich, B. and Lach, S. (1989) 'Entry, Exit and Diffusion with Leaming by Doing', American Economic Review, 79, 690-699.

Karakaya, F. and Stahl, M. J. (1989) 'Barriers to Entry and Market Entry Decisions in Consumer and Industrial Goods Markets', Journal of Marketing, 53, 80-91.

Kessides, I. N. (1986) 'Advertising, Sunk Costs, and Barriers to Entry', Review of Economics and Statistics, 68, 84-95.

Kessides, I. N. (1990) 'Towards a Testable Model of Entry: A Study of the US Manufacturing Industries', Economica, 57, 219-238.

Khemani, R. S. and Shapiro, D. M. (1986) 'The Determinants of New Plant Entry in Canada', Applied Economics, 18, 1243-1257.

Khemani, R. S. and Shapiro, D. M. (1988) 'On Entry and Mobility Barriers', Antitrust Bulletin, 33, 115-134.

Kmenta, J. (1986) Elements of Econometrics, 2nd ed., New York.

Lieberman, M. B. (1987) 'Excess Capacity as a Barrier to Entry: An Empirical Appraisal', Journal of Industrial Economics, 35, 607-627.

MacDonald, J. M. (1986) 'Entry and Exit on the Competitive Fringe', Southern Economic Journal, 52, 640-652.

MacKinnon, J. G. (1992) 'Model Specification Tests and Artificial Regressions',Journal of Economic Literature 30, 102-146.

Mansfield, E. (1962) 'Entry, Gibrat's Law, Innovation, and the Growth of Firms', American Economic Review 52, 1023-1051.

Marcus, M. (1967) 'Firms, Exit Rates and their Determinants', Journal of Industrial Economics, 16, $10-22$.

Masson, R. T. and Shaanan, J. (1982) 'Stochastic-dynamic Limiting Pricing: An Empirical Test', Review of Economics and Statistics, 64, 413-422.

Masson, R. T. and Shaanan, J. (1986) 'Excess Capacity and Limit Pricing', Economica, 53, 365-378.

Masson, R. and Shaanan, J. (1987) 'Optimal Oligopoly Pricing and the Threat of Entry', International Journal of Industrial Organization, 5, 323-339.

Mata, J. (1991) 'Sunk Costs and Entry by Small and Large Plants', in: P. A. Geroski and J. Schwalbach (eds.), Entry and Market Contestability: An International Comparison, Oxford.

Mata, J. (1993) 'Entry and Type of Entrant: Evidence from Portugal', International Journal of Industrial Organization 11, 101-122.

Nooteboom, B. (1986) 'Costs, Margins and Competition: Causes of Structural Change in Retailing', International Journal of Research in Marketing, 3, 233-242.

Orr, D. (1974) 'The Determinants of Entry: A Study of the Canadian Manufacturing Industries', Review of Economics and Statistics, 56, 58-66.

Phillips, B. D. and Kirchhoff, B. A. (1989) 'Formation, Growth and Survival; Small Firm Dynamics in the U.S. Economy', Small Business Economics, 1, 65-74. 
Rosenbaum, D. I. (1993) 'Profit, Entry and Changes in Concentration', International Journal of Industrial Organization 11, 185-203.

Rosenbaum, D. I. and Lamort, F. (1992) 'Entry, Barriers, Exit, and Sunk Costs: An Analysis', Applied Economics, 24, 297-304.

Santarelli, E. and Sterlacchini, A. (1994) 'New Firm Formation in Italian Industry: 1985-89', Small Business Economics, 6, 95-106.

Schmalensee, R. (1989) 'Inter-industry Studies of Structure and Performance', in: R. Schmalensee and R. D. Willig (eds.), Handbook of Industrial Organization, Vol. II, Amsterdam.

Schwalbach, J. (1987) 'Entry by Diversified Firms into German Industries', International Journal of Industrial Organization, 5, 43-49.

Schwalbach, J. (1991) 'Entry, Exit, Concentration, and Market Contestability', in: P. A. Geroski and J. Schwalbach (eds.), Entry and Market Contestability: An International Comparison, Oxford.

Shapiro, D. M. (1983) 'Entry, Exit, and the Theory of the Multinational Corporation', in: C. P. Kindleberger and D. B. Audretsch (eds.), The Multinational Corporation in the 1980s, Cambridge.

Shapiro, D. and Khemani, R. S. (1987) 'The Determinants of Entry and Exit Reconsidered', International Journal of Industrial Organization, 5, 15-26.

Sleuwaegen, L. and Dehandschutter, W. (1991) 'Entry and Exit in Belgian Manufacturing', in: P. A. Geroski and J. Schwalbach (eds.), Entry and Market Contestability: An International Comparison, Oxford.

Storey, D. J. (1991) 'The Birth of New Enterprises - Does Unemployment Matter? A Review of the Evidence', Small Business Economics, 3, 167-178.

Vogelesang, W., Broadbridge, A., and Zanderighi, L. (1992, eds.), Distributive Trades in ECcountries, Zoetermeer.

Von der Fehr, N. H. M. (1991) 'Domestic Entry in Norwegian Manufacturing Industries', in: P. A. Geroski and J. Schwalbach (eds.), Entry and Market Contestability: An International Comparison, Oxford.

Wagner, J. (1994) 'Small Firm Entry in Manufacturing Industries: Lower Saxony, 1979-1989', Small Business Economics 6, 211-223.

Yamawaki, H. (1991) 'The Effects of Business Conditions on Net Entry, Evidence from Japan', in: P. A. Geroski and J. Schwalbach (eds.), Entry and Market Contestability: An International Comparison, Oxford. 